\title{
Relationship between Adaptive Capability and Strategic Orientation: An Empirical Study in a Brazilian Company
}

\author{
Cristiano Kaehler, Franciele Busatto, Grace V. Becker, Peter Bent Hansen, \\ Jane Lucia S. Santos \\ School of Business Administration (PPGAd), Pontifical Catholic University of Rio Grande do Sul (PUCRS), Porto \\ Alegre, Brazil \\ Email: cristianogk@gmail.com, fran.busatto@hotmail.com, grace.becker@pucrs.br, \\ peter.hansen@pucrs.br, janejlss@gmail.com
}

Received 26 December 2013; revised 25 January 2014; accepted 24 February 2014

Copyright (C) 2014 by authors and Scientific Research Publishing Inc.

This work is licensed under the Creative Commons Attribution International License (CC BY). http://creativecommons.org/licenses/by/4.0/

(c) (i) Open Access

\begin{abstract}
The main purpose of this article is to examine the relationship between adaptive capability and strategic orientations in the organizational context. In order to achieve this, an empirical study was carried out in a Brazilian agency for maritime services, via a survey of 160 employees. The results show a positive correlation between all of the strategic orientation variables and their respective adaptive capability. That is, the findings show that the company's strategic orientations affect its adaptive capability, and also suggest that the stronger the respondents' perception of the company's dynamic capability, the higher its organizational adaptive capability in its market of operation.
\end{abstract}

Keywords

Adaptive Capability; Strategic Orientation; Dynamic Capability

\section{Introduction}

The resource-based and dynamic-capability views have been influencing researchers for decades, by providing a theoretical perspective on the field of strategic management [1], [2]. This has led to further reflections on organizations' competitive advantage [3]-[6]. Adopting a positioning or an ongoing improvement strategy in order to achieve better operational efficiency — an area that many researchers have focused on — has proved to provide a static logic that is insufficient with respect to following changes in a complex and dynamic environment, marked 
by disturbances and uncertainties [5], [7], [8].

The concerted effort to understand how a company adapts to environmental challenges and opportunities is not a recent academic research topic. Originally, studies have indicated that the organizational adaptation process is related to the company actions and decision-making process when confronting the conditions of the market [9]-[11]. This means that adaptation capability is strongly linked to strategic actions that aim towards the reconfiguration of organizational resources, competences and routines in order to meet demands and opportunities within a changing business environment [2], [5], [6]. Characterized by the company's ability to implement strategies and actions to meet market changes, dynamic capability gives rise to organizational adaptive capability.

Once the adaptive capability is tied to the strategic action, it presents strong links with the organization's strategic orientation. Strategic orientation is responsible for defining the outline of the company's strategy, influencing its decisions, and conducting organizational efforts and investments [12]. Strategic orientation reflects the organizational choices and the way in which the company has to interact with the external environment while doing business, as well as how to reconfigure, use or acquire resources in order to create dynamic capabilities [13].

Thus, a virtuous circle is established between adaptive capability and organizational strategic orientations. Within this process, dynamic capabilities are highlighted that, once recognized and connected to the company's strategic orientation, they provide fuel for the organizational adaptive cycle. This is the basic idea that inspired this article and that has been developed via examination of the relationship between adaptive capability and strategic orientations in a maritime service provider. The relationship between these elements becomes relevant for understanding the drivers of high organizational performance [7], [13].

\section{Theoretical Background}

\subsection{Adaptive Capability}

In trying to better understand how a company adapts to environmental challenges and opportunities, Miles and Snow [9] developed a typology that portrays organizational strategic behavior. This typology distinguishes four behavioral patterns: defenders, prospectors, analyzers and reactors, depending on how a company responds to the major problems, i.e. entrepreneurial, engineering, and administrative problems. Desarbo et al.'s [11] studies broadened this model and added a new typology group, in the form of strategic capabilities, performance, and environmental factors to the original four types of behavior. Differently, the model presented by Hrebiniak and Joyce [10] is based on an interrelation between environmental determinism and the number of strategic choices or organizational reactions. When these aspects are crossed, they allow the development of a typology of organizational adaptability, whose interactions result in the identification of four main types of adaptation: "natural selection", "differentiation", "strategic choice" (which includes characteristics of [9] prospective vision) and, finally, "undifferentiated choice". The presented models point out that adaptive capability is strongly linked to the company's strategic action with respect to changing its abilities, resources and organizational competences in order to meet the requirements of a changing environment [5], [9].

In this context, it has to be noted that companies are held hostage by their own trajectories, so that they become dependents on their own strategic choices that will influence their current and future capabilities and organizational processes [5], [14]. In this world of constant change, becoming competitive requires continuous adaptation and strategic flexibility. Old decisions concerning how to manage organizational capabilities could make the company a prisoner of the past, thereby constraining future success [14]. Different companies under the same environmental conditions can also be led, by external pressure, to become increasingly alike, thereby creating a constraining isomorphic process in the search for power and institutional legitimacy [15].

In this work, adaptive capability is considered to be the organization's strategic ability to maintain competitive advantage by modifying, reconfiguring or interconnecting resources, capabilities and competences, and seeking to increase the number of options or available strategic reactions in order to adapt quickly to determinism and environmental changes.

\subsection{Strategic Orientation}

Effective strategic orientation depends on both the market dynamics and the levels of environmental uncertainty and competitiveness. This strategic orientation reflects organizational choices, the way the company interacts 
with the external environments, and how it manages its business, and allocates, modifies, reconfigures, uses or acquires resources in order to create dynamic capabilities [13]. In this article, strategic stakeholder orientations have been considered by focusing on two groups-customers and competitors-and their technological and cost orientation [16]-[18]. The stakeholder theory considers that the essence of competitive advantage lies in the simultaneous combination of all different relevant stakeholders, with an economic effect, whose changes are derived from both external and internal relations [16]. Stakeholder orientation refers to how the company succeeds in fulfilling the interests of all relevant stakeholders [19]. Among these interest groups, customers are considered to be subject to greatest change, as well as being the most difficult to understand [19]. Nowadays, a wide variety of choices are offered to consumers, who also regularly demand new patterns of quality [16]. Maintaining a proactive disposition, giving continual priority to value creation, and keeping track of consumers' habits, needs and changes in preferences, is part of the scope of customer orientation. When a behavior change is identified, it is possible to mobilize resources in order to modify, customize or develop new products or services in accordance with consumer preferences [13], [20]. However, a competitor orientation seeks to monitor competitors by evaluating their strengths and weaknesses, and by comparing their resources, costs and financial performance. By collecting this information, the company is able to implement resources and develop capabilities to face competitive environments [13], [21]. The company's priority is to evaluate competitor targets, strategies, offers, resources and capabilities, and gather useful information to equal or overcome rival strengths [20]. In highly competitive environments, it is necessary to keep track of rivals in order to react quickly; in addition, as stated by [22], competitor orientation is one of the main dimensions of influence in the company's performance.

Technology orientation allows the company to keep updated by investing in technology resources. This orientation helps to improve existing organizational competences, create new products in order to meet environmental changes, identify new trends in technology, and modify resources that aim to capitalize on opportunities [13], [21]. Zhou and Li [13] suggest that customer orientation and technology orientation can have a positive effect on organizational adaptive capability. Narver and Slater [18] analyzed the correlation between variables linked to market orientation, and the company's profitability. They pointed out the relationship between profitability and cost-reduction policy, which strongly affects other activities linked to research and development, production, services, sales and advertising. Yasin, Bayes and Czuchhry [23] added that cost-reduction policy has to consider other activities that do not add direct value to the business, represented as "quality costs".

Cost orientation consists of directing an organization to achieve efficiency in the complete value chain, and aiming to reduce costs in both primary and support activities, which means that it is oriented towards the internal environment [17], [20]. Even with companies taking control over the internal aspects of the business, cost is coupled with innovation, and this condition makes products and strategies hard to detect and imitate by competitors [24].

Considering the above, in this study strategic orientation is defined as a guiding principle, which is highly dependent on the market dynamic that leads and influences a company's ability to allocate, reconfigure, modify, use and/or acquire resources and capabilities.

\section{Method}

The empirical research in this article took the form of a survey conducted in a Brazilian maritime service provider. The company chosen is the oldest and most prominent maritime agency in Brazil. It acts on behalf of ship-owners and charterers, offering services related to commercial representation, documents, container control, demurrage control and ship attendance. Its offices (units) are located in 18 different Brazilian cities spread over the country. Through these offices, the company covers the whole of the national territory, with more than 46 maritime ports (including all of the main ports). The company operates in two large markets; the first deals with liner shipping and the second with tramp shipping. Its main customers are both domestic and foreign traders and ship-owners. All of the government agencies, including Receita Federal, Agência Nacional de Vigilância Sanitária (ANVISA), Polícia Federal, and Capitania dos Portos, as well as the port authorities, count on maritime agents to observe laws, rules and regulations during the different procedures involved in the arrival, entry, berthing, maneuvering and departure of ships.

In the empirical study, 273 employees from the case company were used as the target population, and 160 responded to the survey - that is, $58.60 \%$ of the total (Table 1 ).

Out of the 160 respondents, $57 \%$ are male and $43 \%$ female; $18 \%$ are between 18 and 25 years old, $43 \%$ be- 
Table 1. Population and respondents.

\begin{tabular}{ccccc}
\hline Position/function & Population & $\mathbf{\%}$ & Respondents & \% \\
\hline Assistant/analyst/operator & 214 & 78.39 & 108 & 50.47 \\
Supervisor/coordinator/manager & 49 & 17.95 & 42 & 85.71 \\
Branch manager/regional manager/board of directors & 10 & 3.66 & 10 & 100.00 \\
TOTAL & $\mathbf{2 7 3}$ & $\mathbf{1 0 0 . 0 0}$ & $\mathbf{1 6 0}$ & 58.61 \\
\hline
\end{tabular}

Source: Authors.

tween 26 and 35, 25\% between 36 and 45, 13\% between 46 and 55 and 1\% between 56 and 65; 23\% have been working for the company for less than a year, 42\% between 1 and 5 years, 14\% between 6 and 10 years, 8\% between 11 and 15 years, 7\% between 16 and 20 years and $6 \%$ for more than 21 years. In addition, $72 \%$ confirmed that they have direct contact with organization's customers.

The constructs analyzed in this study were measured using a five-point Likert scale from 1 (totally disagree) to 5 (totally agree), with the added option "I don't know". The electronic questionnaire was developed using Qualtrics Survey Software, and was composed of 32 statements based on the constructs of strategic orientation and adaptive capability (Figure 1). All of the statements were based on previous studies [5], [10], [13]-[15], [17]. Each construct was assigned a code to demonstrate the correlation between the constructs, for example: O1, $\mathrm{O} 2$... O16 to represent strategic orientation, and A1, A2 ... A16 to represent adaptive capability (Figure 1).

The instrument also presented nine open questions in order to help the respondents to identify and recognize possible dynamic capabilities. Moreover, six questions related to the respondents' profiles were used in this questionnaire.

The study was started in 2011 and finished in 2012. After collection, the data was analyzed using SPSS (version 17.0) software, and summarized to facilitate its presentation. This article assumes that descriptive research considers the frequency or extension of the relationship between two variables [25]. The relationships between the various strategic orientations and adaptive capabilities in the company are displayed on a graph, whose $\mathrm{x}$-axis contains the low or high adaptation capability data, and whose y-axis contains the low or high strategic orientation data. The level was calculated on the basis of the average obtained for every group of answers related to customer, competitor, technology and cost orientations, and also for the group of answers related to adaptive capabilities. Recognition of dynamic capabilities was investigated through an analysis of the answers to the open questions. The next section presents a synthesis of results based on analysis of the collected evidence.

\section{Results}

To analyze the existing correlations between adaptive capability and the company's strategic orientation, it was considered that these correlations showed various strengths of association, classified as very strong (coefficient +0.91 to +1.00 ), high (from +0.71 to +0.90 ), moderate (from +0.41 to +0.70 ), small but distinct (from +0.21 to +0.40 ), and light (from +0.01 to +0.01 ) [26].

The correlations existing between the variables were used to measure the level of customer, competitor, technology and cost orientations and their respective adaptive variables (Figure 2). The results show positive correlations between all strategic orientation variables and their respective adaptive capabilities.

The analysis of data collected from the Brazilian maritime service provider establishes that cost, customer and technology orientations, and its adaptive capabilities, have the highest level of orientation and adaptability, according to the respondents. Competitor adaptive capability is high, and its orientation is considered moderate. On the other side, there is a high technology orientation in conjunction with a high adaptive capability (Figure 3).

The following section will discuss the correlations between strategic orientation and adaptive capability in the case company.

\subsection{Technology Orientation and Adaptability}

The implementation of modern and intelligent information systems is an essential strategic factor for maritime companies, and makes it possible to utilize services such as electronic bill of lading $(\mathrm{eB} / \mathrm{L})$ and connection with other systems, such as Siscomex (Sistema Integrado de Comércio Exterior), Siscarga (Sistema Integrado para Cargas), PSP (Porto sem Papel), as well as customers' systems. It is important for the company to keep up with 
$\mathrm{O} 2$ - Information sharing about the organization's customers.

O3 - Knowledge and measurement of customer satisfaction.

O4 - Value creation for customers.

O5 - Discovery of unconscious/hidden customer needs.

Competitor orientation:

O6 - Gathering and sharing of information about competitor activities.

07 - Reaction to competitor threats.

O8 - Debates about competitor strengths, weaknesses and strategies.

O9 - Identification of areas in which main competitors have succeeded or failed.

Technology orientation:

010 - Service achievement with the best technology.

011 - Use of new technologies in improvement projects.

012 - High investments in technology.

013 - Identification of new technological trends that help services.

Cost orientation:

014 - Cost reduction decreases prices for customers.

$\mathbf{O 1 5}$ - Cost reduction in all company's sectors.

016 - Economies of scale with low price are an important strategic

element.

A1 - Competences allow market demands to be met.

A2 - Service adaptability to customers' real needs.

A3 - Anticipation of customers' evolutionary needs.

A4 - Service adaptability to customers' current needs.

A5 - Intentionality and proactivity in strategic actions.

Competitors:

A6 - Differentiated services according to important factors.

A7 - Imitation of service models by competitors.

A8 - Adaptation of activities focused on facing the competitive environment.

A9 - Intentionality and proactivity in competitive actions.

Technology:

A10 - Implementation of new technologies.

A11 - Use of new technologies in the organization.

A12 - Service differentiation through technological resources as an answer to environmental changes.

Costs:

A13 - Competitive costs.

A14 - Adaptation to pressures linked to operational costs.

A15 - Activities adapted to pressures of lower costs.

A16 - Intentionality and proactivity in price policies.

Figure 1. Closed questions_ constructs: Strategic orientation and adaptive capability.

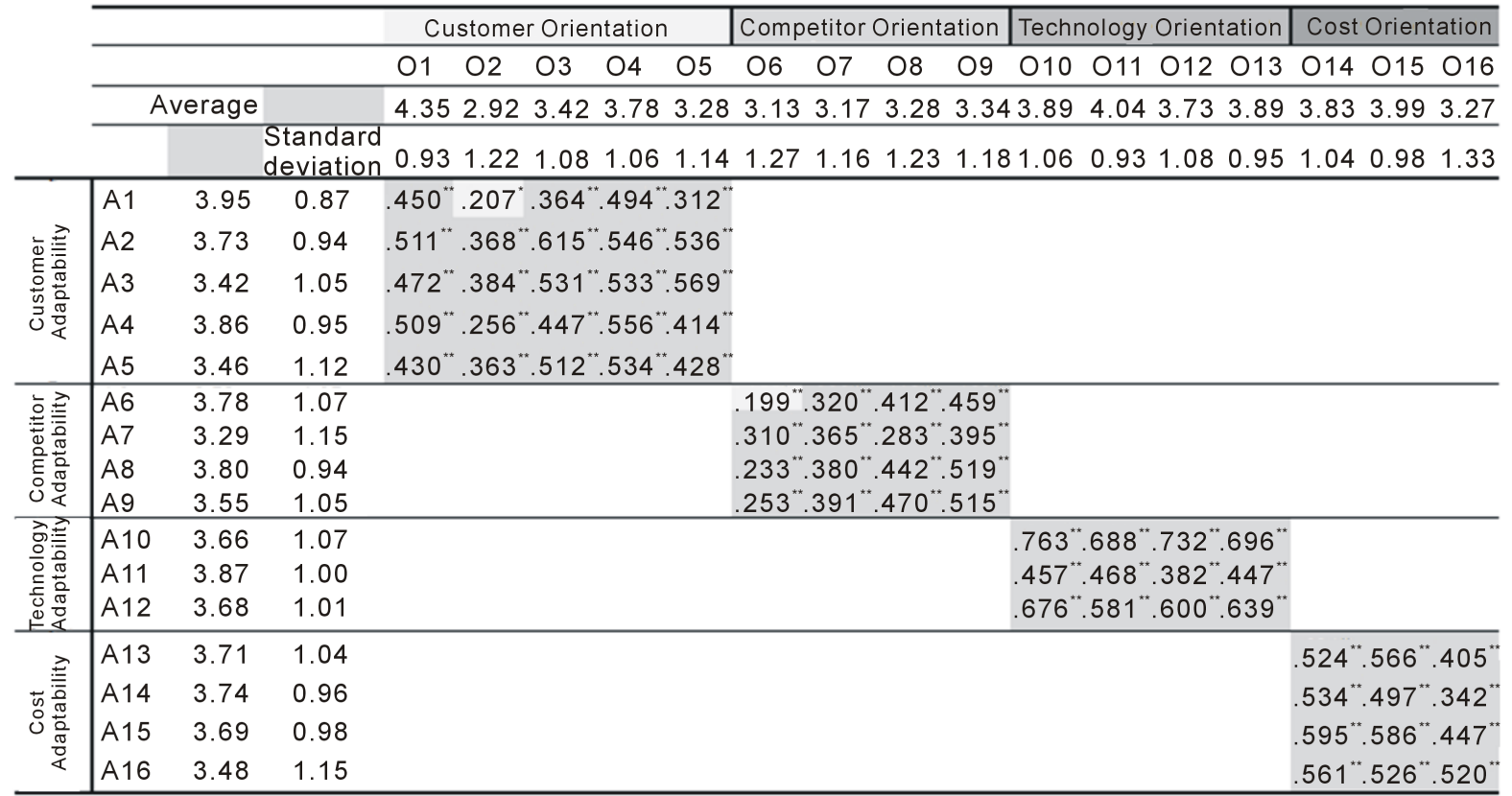

Figure 2. Descriptive statistics and correlations between strategic orientations and adaptive capability. ${ }^{*}$ Correlation on level of significance 0.005 (two-sided); ${ }^{* *}$ Correlation on level of significance 0.001 (two-sided) $\mathrm{N}=160$.

developments in communication equipment that helps customer service, in order to ensure that the company has all of the relevant information for customers, and facilitate the quick delivery of documents. In order to keep up with technology developments, the company has invested in training programs, the development of its own IT systems, and the use of new communication technologies for seeking to identify and anticipate possible market trends. The results of the current research are compatible with a statement made by [13], which stated that technology orientation can have a positive influence over an organization's adaptive capability.

There is a significant correlation between all adaptive capabilities and the strategic orientations analyzed (Figure 2). Among those that show the highest strength in their association, new technologies appear to have been frequently implemented into the company, with a high and positive correlation coefficient of 0.763 for research into the best technology, and 0.732 , for high investments. This correlation suggests that the stronger the 


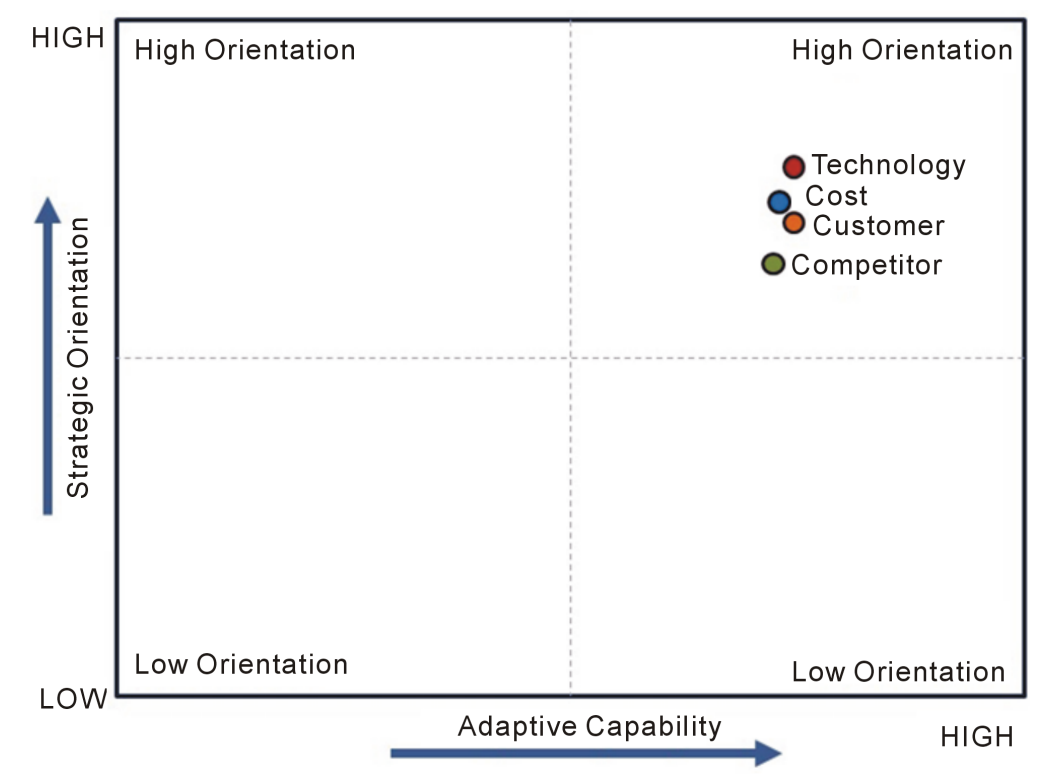

Figure 3. Relation between strategic orientations and adaptive capability in the case company.

company's ability to implement new technologies, the stronger its orientation will be to look for, use and invest in technology, since the use of new technologies is already largely accepted by the company's employees (average 3.87), as seen in Figure 2.

Technology orientation proved to be stronger than cost, customer and competitor orientations. As pointed out by [13], the more uncertain the market demand, the less important customer orientation, and the technology orientation is more predominant. However [22] pointed out that in a highly competitive environment it becomes necessary for continuous competitor monitoring in order to react quickly, which means that competitor orientation appears to be one of the main dimensions that could influence organizational performance.

Three dynamic capabilities are essential within the case company: developing new IT technologies, foreseeing technological changes, and keeping employees updated and trained. The collected data suggests that recognition of dynamic capabilities increases the company's adaptability to both external and internal environments, as well as the accomplishment of strategic actions, which are deliberated and influenced by its technology orientation.

\subsection{Cost Orientation and Adaptability}

Headings, or heads, are organizational devices that guide the reader through your paper. There are two types: component heads and text heads.

The second orientation highlighted in this work refers to a high cost orientation and high adaptive capability. The main pressures appear to be a need for cost and resource savings; recycling or cutting down superfluous expenses; and the configuration of a leaner structure through the implementation of a center of services, which is shared by the diverse business units. In addition, the demand for services that have a low price and high quality; competitors' low pricing policies; changing customer behavior; as well as other pressures, have led the company to adopt diverse strategic actions in order to adapt to the business environment. Among the main adaptations identified is the adoption of a cost-reduction policy, which has involved numerous specific actions and significant cost-reduction programs and restructuring; a better negotiation process with customers; changes in the organizational structures and processes; and the strategic distribution of activities.

Even without submitting to the pressure of offering very low prices, the company uses a cost reduction strategy in its processes in order to obtain better prices and profits. It can be noted that all correlations were significant (Figure 2). Among those that present the biggest strength of association, the relation between "activities adaptation to pressures of lower costs-A15", and "cost reduction orientation that decreases prices for customers - 014", which have a moderate correlation (0.595), and between "activities adaptation to pressures of lower 
costs_A15” and “cost reduction in all company’s sectors_-O15” (0.586) are notable.

The main capabilities generated by the interaction of cost orientation and adaptive capability, were the company's capability with respect to modifying its organizational structure, and to implementing effective cost reduction and expense control programs. The results for orientation and adaptability to cost pressures show that the company directs its actions towards what [23] call quality costs.

\subsection{Customer Orientation and Adaptability}

The third orientation highlighted in this study refers to a high customer orientation and high adaptive capability. Among the main identified needs is the demand for higher proactivity, agility, accuracy and service availability; low prices, while maintaining high-quality service; and the provision of relevant information and market intelligence systems, by having closer contact with customers in order to adapt the service to their needs. High investments in technology and communication equipment, employee training and development, strategic management of quality and service customization were some of the strategic actions that the company has implemented to adapt to customer' real needs.

A moderate correlation (Figure 2) can be noted between the prioritization of value creation and the adaptability of services to the customers' real needs (0.546), to the customer's current needs (0.556) and to the evolutionary needs (0.533). A moderate and positive correlation (0.569) was also noted between ability to anticipate customers' evolutionary needs, and investigation of their unconscious needs. It is further noted that there is a conservative tendency in the sharing of critical information about customers at all organizational levels. The ability to integrate technologies, to keep employees trained, and to strategically manage and customize the quality of services are the main dynamic capabilities identified in relation to the company's process of adaptation to meet customers' needs. These capabilities lead the strategic orientation to be aware of and measure customer satisfaction, prioritizing value creation. In turn, these results present a vision that differs from that given by [13], who say that, in fast-changing environments, customers are not always a trustworthy source of information.

\subsection{Competitor Orientation and Adaptability}

The data collected shows that the figure obtained for sharing information about competitors (average 3.29) is higher than that for sharing information about customers (average 2.92). To explain this fact, some authors have pointed out that in environments with a high level of uncertainty and fast changes, organizations seek information and intelligence about their competitors in order to identify new trends and take possible competitive actions [13], [21], [27]. With a moderate orientation, but a high adaptive capability, competitor orientation comes last in the company's strategic orientations. The reduction of prices charged for services, greater commercial aggressiveness, strong market adaptation, and a focus on both quality and customer relationship management by the rival company are some of the main threats from the employees' viewpoint. To cope with these threats, the company seeks to adapt by providing employee training and hiring commercial specialists, in order to offer services that are perceived as being of higher quality, adopt new technologies, and develop IT systems, among other initiatives.

The analysis of competitor orientation and adaptability correlations (Figure 2) shows that the adaptation of activities to face the competitive environment is moderate and positively correlated (0.519) with the identification of areas in which the main competitors have succeeded or failed. In studies conducted by [13], competitor capability shows little influence on adaptive capability. Contrarily, the present article identifies a moderate correlation between competitor strategic orientation and organizational adaptive capability. This suggests that adaptive capacity can be positively affected by competitor orientation.

The analysis of competitor information in economic environments in which opportunistic competitiveness, unjustness and dishonesty is widespread makes the task more difficult. In addition, competitors could be unaware of the customers' need, which makes competitor orientation less relevant to the development of adaptive capability. Alternatively, the company could pursue the development of its own competences, in order to offer a set of activities and products that are highly differentiated, and thus deliver a unique mix of value [13], [28]. According to [13], the search for differentiation is what distinguishes the adaptive capability of the activities in the company examined in this work. Employee training capability, quality management capability, IT technological capability and development capability are the dynamic capabilities highlighted by the respondents as the most effective ones by which to cope with competitor threats, thereby affecting adaptive capability in these areas. 


\section{Conclusions}

Efforts to understand how companies adapt to environmental challenges and opportunities are increasing. However, there is still a lack of development in this field of research. It is necessary to fill the research gaps about strategic orientation and organizational adaptive capability, since there have been few initiatives to approach and visualize the subject through empirical evidence. In addition, studies involving companies from the maritime services sector are quite scarce, as pointed out by [29]. This study has been driven by this fact.

The collected data indicate that adaptive capability is influenced at different levels by strategic orientations, and that all of the results are significant. This relation also suggests that the higher the respondents' perception of the company's dynamic capabilities, the higher the organization's adaptive capability to the market.

There is one specific limitation of this study that has to be mentioned. Obviously, the degree of influence in the relationship between strategic orientations and adaptive capabilities might vary depending on both the company analyzed and the market dynamics surrounding it. New studies could be developed based on this article; for example, analyses could be conducted on the influence of internal and external environments in each of the identified orientations and capabilities, or on the relationship between strategic orientation and essential competences, and the way these competences develop over time.

\section{References}

[1] Wu, L.-Y. (2010) Applicability of the Resource-Based and Dynamic-Capability Views under Environmental Volatility. Journal of Business Research, 63, 27-31. http://dx.doi.org/10.1016/j.jbusres.2009.01.007

[2] Ambrosini, V. and Bowman, C. (2009) What Are Dynamic Capabilities and Are They a Useful Construct in Strategic Management? International Journal of Management Reviews, 11, 29-49.

http://dx.doi.org/10.1111/j.1468-2370.2008.00251.x

[3] Wernerfelt, B. (1984) A Resource Based View of the Firm. Strategic Management Journal, 5, 171-180. http://dx.doi.org/10.1002/smj.4250050207

[4] Barney, J. (1991) Firm Resources and Sustained Competitive Advantage. Journal of Management, 17, 99-120. http://dx.doi.org/10.1177/014920639101700108

[5] Teece, D.J., Pisano, G. and Shuen, A. (1997) Dynamic Capabilities and Strategic Management. Strategic Management Journal, 18, 509-533. http://dx.doi.org/10.1002/(SICI)1097-0266(199708)18:7<509::AID-SMJ882>3.0.CO;2-Z

[6] Teece, D.J. (2012) Dynamic Capabilities: Routines versus Entrepreneurial Action. Journal of Management Studies, 49, 1395-1401. http://dx.doi.org/10.1111/j.1467-6486.2012.01080.x

[7] Winter, S.G. (2003) Understanding Dynamic Capabilities. Strategic Management Journal, 24, 991-995. http://dx.doi.org/10.1002/smj.318

[8] Teece, D.J. (2007) Explicating Dynamic Capabilities: The Nature and Microfoundations of (Sustainable) Enterprise Performance. Strategic Management Journal, 28, 1319-1350. http://dx.doi.org/10.1002/smj.640

[9] Miles, R. and Snow, C. (1978) Organizational Strategy, Structure, and Process. The Academy of Management Review, 3, 546-562.

[10] Hrebiniak, L.G. and Joyce, W.F. (1985) Organizational Adaptation: Strategic Choice and Environmental Determinism. Administrative Science Quarterly, 30, 336-349. http://dx.doi.org/10.2307/2392666

[11] DeSarbo, W.S., Di Benedetto, C.A., Song, M. and Sinha, I. (2005) Revisiting the Miles and Snow Framework: Uncovering Interrelationships between Strategic Types, Capabilities, Environmental Uncertainty and Firm Performance. Strategic Management Journal, 26, 47-74. http://dx.doi.org/10.1002/smj.431

[12] Slater, S.F., Olson, E.M. and Hult, G.T. (2006) The Moderating Influence of Strategic Orientation on the Strategy Formation Capability-Performance Relationship. Strategic Management Journal, 27, 1221-1231. http://dx.doi.org/10.1002/smj.569

[13] Zhou, K.Z. and Li, B.C. (2010) How Strategic Orientations Influence the Building of Dynamic Capability in Emerging Economies. Journal of Business Research, 63, 224-231. http://dx.doi.org/10.1016/j.jbusres.2009.03.003

[14] Schreyogg, G. and Kliesch-Eberl, M. (2007) How Dynamic Can Organizational Capabilities Be? Towards a DualProcess Model of Capability Dynamization. Strategic Management Journal, 28, 913-933. http://dx.doi.org/10.1002/smj.613

[15] Dimaggio, P.J. and Powell, W.W. (2005) A Gaiola de Ferro Revisitada: Isomorfismo Institucional e Racionalidade Coletiva nos Campos Organizacionais. Revista de Administração de Empresas, 45, 74-89.

[16] Freeman, R.E. (2010) Strategic Management: A Stakeholder Approach. Cambridge University Press, Cambridge. 
[17] Porter, M.E. (1985) Competitive Advantage-Creating and Sustaining Superior Performance. The Free Press, New York.

[18] Narver, J.C. and Slater, S.F. (1990) The Effect of a Market Orientation on Business Profitability. Journal of Marketing, 54, 20-35. http://dx.doi.org/10.2307/1251757

[19] Greenley, G.E. and Foxall, G.R. (1996) Consumer and Nonconsumer Stakeholder Orientation in UK Companies. Journal of Business Research, 35, 105-116. http://dx.doi.org/10.1016/0148-2963(95)00052-6

[20] Olson, E., Slater, S.F. and Hult, T.M. (2005) The Performance Implications of Fit among Business Strategy, Marketing Organization Structure, and Strategic Behavior. Journal of Marketing, 69, 49-65. http://dx.doi.org/10.1509/jmkg.69.3.49.66362

[21] Gatignon, H. and Xuereb, J. (1997) Strategic Orientation of the Firm and New Product Performance. Journal of Marketing Research, 34, 77-90. http://dx.doi.org/10.2307/3152066

[22] Noble, C.G., Sinha, R.K., and Kumar, A. (2002) Market Orientation and Alternative Strategic Orientations: A Longitudinal Assessment of Performance Implications. Journal of Marketing, 66, 25-39. http://dx.doi.org/10.1509/jmkg.66.4.25.18513

[23] Yasin, M.M., Bayes, P.E. and Czuchry, A.J. (2005) The Changing Role of Accounting in Supporting the Quality and Customer Goals of Organizations: An Open System Perspective. International Journal of Management, 22, 323-331.

[24] Dickson, P.R. (1992) Toward a General Theory of Competitive Rationality. Journal of Marketing, 56, 69-83. http://dx.doi.org/10.2307/1252133

[25] Dillon, W.R., Madden T.J., and Firtle, N.H. (1994) Marketing Research in a Marketing Environment. Burr Ridge, Irwin.

[26] Hair, J.F., Babin, B., Money, A.H. and Samouel, P. (2005) Fundamentos de Métodos de Pesquisa em Administração. Bookman, Porto Alegre.

[27] Slater, S.F. and Narver, J. (1998) Customer Led and Market Oriented: Let’s Not Confuse the Two. Strategic Management Journal, 19, 1001-1006. http://dx.doi.org/10.1002/(SICI)1097-0266(199810)19:10<1001::AID-SMJ996>3.0.CO;2-4

[28] Porter, M.E. (1996) What Is Strategy. Harvard Business Review, 61-78.

[29] Kaehler, C. (2013) Framework de Avaliação de Competências Organizacionais: O Caso de Uma Empresa Brasileira de Agenciamento Marítimo. Dissertação de Mestrado, Programa de Pós Graduação em Administração da PUCRS. 